\title{
A Comparative Histomorphometric Study of the Stomach of Rat (Rattus norvegicus), Bat (Eidolon helvum) and Pangolin (Manis tricuspis) in Relation to Diet
}

\author{
Estudio Comparativo Histomorfométrico del Estómago de Rata (Rattus norvegicus), \\ Murciélago (Eidolon helvum) y Pangolín (Manis tricuspis) en Relación con la Dieta \\ Ofusori D. A. \& Caxton-Martins, E. A.
}

OFUSORI, D.A. \& CAXTON-MARTINS E. A. A comparative histomorphometric study of the stomach of rat (Rattus norvegicus), bat (Eidolon helvum) and pangolin (Manis tricuspis) in relation to diet.Int. J. Morphol., 26(3):669-674, 2008.

SUMMARY: This study verified the comparative histomorphometric adaptations in the stomach of rat, bat and pangolin in relation to diet. Ten rats, ten bats and ten pangolins of both sexes were used for this investigation. The animals were sacrificed after slight anesthesia under chloroform inhalation. The stomach were excised, fixed in $10 \%$ formol saline and processed for light microscopic study. Stained slides were also subjected to morphometric analysis at a magnification of 400x. The results revealed that the cellular diameter/ density of parietal and zymogenic cells are significantly different in the three mammals $(\mathrm{p}<0.05)$ with the exception of the diameter of the zymogenic cells in pangolin which was not statistically significant ( $p>0.05$ ) when compared with that of rat. Also, histological analysis revealed slight differences in the pattern of organization and distribution of connective tissue fibers. All these observations were reflections of the different pattern the stomachs of the three mammals have adopted to cope with their respective diets.

KEY WORDS: Pangolin; Bat; Rat; Stomach; Histomorphometry; Connective tissue fibers.

\section{INTRODUCTION}

The stomach, a component of the gastrointestinal tract, performs the function of storage and churning of food in to a semi liquid called chyme. Histological view of the stomach presents an adaptation favouring the diets of a particular animal (Ofusori et al., 2007). The histoarchitectural organization including the distribution of connective tissue fibers provides a useful interpretation of the adaptational mechanisms adopted by the gut of different animals in coping with their diets (Hildebrand \& Goslow, 2001).

Connective tissues also known as supporting tissue provides structural and metabolic support for other tissues and organs throughout the body (Heat et al., 1999). They are mesodermal in origin and mediate the exchange of nutrients, metabolites and wastes products between tissues and circulatory system. The fibrous components of supporting tissues are of two types: collagen and elastin. The presence, arrangement and distribution of the connective tissue fibers in the stomach have been known to be related to specific diet (Ofusori \& Caxton-Martins, 2005).
Pangolin, bat and rat are mammals with different diets. Pangolin (Manis trisuspis) commonly found in the western region of Nigeria, consumes insect and termites (Kingdon, 1974; Griffiths et al., 1990). Although pangolin has no teeth to masticate, the stomach has been reported to play a vital role in the churning of the ingested arthropods (Redford \& Dorea, 1984; Ofusori et al.). The nutrients needed from the ingesta are found in the soft internal part well shielded with the chitin (Redford, 1983, 1985). The latter must be removed to expose the nutrients rich in fat and protein. The bat (Eidolon helvum) is frugivorous (Okon, 1974). Studies have been done on straw -coloured fruit-eating bat by investigators including Okon, Mutere (1967), Ayensu (1974) and Ofusori \& Caxton-Martins. Okon gave preference to Eidolon helvum within the Obafemi Awolowo University Campus were the bats formed a vast colony. Mutere analyzed the various fruits eating by Eidolon in Uganda. Ayensu revealed the interactions between fruit bats and plants with special reference to Ghana. Reports from Ofusori \& CaxtonMartins also showed that the bats through their feeding habits

\footnotetext{
* Department of Anatomy and Cell Biology, Faculty of Basic Medical Sciences, Obafemi Awolowo University, Ile-Ife, Osun State. Nigeria.
} 
bring about pollination. Rouk \& Glass (1970) in their work on the blood sucker bats, revealed the gastric morphology of Desmodus in relation to diet. Rats (Rattus norvegicus) are omnivores. It always finds something to eat but the most important is to know what is edible and what is poisonous (Caroline \& Gross, 2003). Rats can also choose nutrients, preferring low carbohydrate diets (Ofusori \& CaxtonMartins).

The cellular component of the stomach consisted of a mixed population of cells of three main types: mucussecreting cells, acid secreting cells (parietal cells) and pepsinsecreting cells (zymogenic cells) (Heath et al.). The secretory activities of these cells is controlled by the autonomic nervous system and the hormone gastrin secreted by endocrine cells mainly located in the pyloric region.

This investigation aims at comparatively examining the adaptational mechanism the stomachs of the three mammals have adopted to cope with their respective diets using histomorphometric method.

\section{MATERIAL AND METHOD}

Care of the animals. Ten rat, ten bats and ten pangolins of both sexes were used for this investigation. The pangolins were procured $24 \mathrm{~h}$ prior to sacrifice from Asejire, a local village in the North West of Osun state, Nigeria. The bats were curled down from their roosting colony on the Obafemi Awolowo University Campus following ethical clearance and maintained in the Animal Holdings of the Department of Anatomy and Cell Biology, Obafemi Awolowo University, Ile-Ife, Nigeria. They were fed with ripe bananas and water liberally. Rats were obtained and maintained in the Animal Holdings of the same Department. The animals were carefully assessed and confirmed to be in normal state of health. The handling and care of the animals conform to the animal right committee of the Obafemi Awolowo University campus, Ile-Ife, Nigeria.

Surgical procedure. The animals were anesthetized under chloroform inhalation and the stomach harvested following midline-abdominal incision. The tissues were perfuse with physiological saline and blotted dry on a filter paper.

Histological analysis. Tissues were fixed in $10 \%$ formol saline for $48 \mathrm{~h}$ and processed routinely for paraffin embedding. Serial sections were obtained at $5 \mu \mathrm{m}$ thickness from a rotary microtome and subjected to the following staining procedures: heamatoxylin and eosin (H\&E), Van Gieson and Verhoeff's heamatoxylin elastic tissue stain.
Morphometric assessment. The diameters and densities of parietal and zymogenic cells were measured from slides stained with H\&E. The diameters of the cells were measured using the method of W.H.O (1991) in which an occulometer was inserted into the microscope and focused through stained slides. The cellular density was analyzed adopting the method of W.H.O in which a grid was inserted into the eye piece of the microscope and focused through stained sections of tissues. All the cells were enumerated and corrections were made for cells bisected by the edges or borders of the grid. The cell population was estimated at number of cells $/ \mathrm{mm}^{2}$ of tissue. The counting was done at a magnification of $\mathrm{x} 400$. Sala et al., (1981) mathematical correction was used to correct for the actual number of cells counted.

Statistical analysis. Data were expressed as mean \pm SEM and analyzed by student's t-test using statistical software STATISTICA VERSION 5. Differences below the 0.05 $(\mathrm{P}<0.05)$ were considered significant.

\section{RESULTS}

Morphometric analysis. The parietal cells of the rat are the largest $(6.3 \pm 0.62 ; \mathrm{p}<0.05)$ and less numerous $(5.3 \pm 0.31$ cells $/ \mathrm{mm}^{2}$ ) as compared with the other two mammals (bat and pangolin) (Tables I and II). The morphology of the parietal cells revealed an extensive eosinophilic cytoplasm and centrally located nucleus. The diameter of the zymogenic cells were also observed to be largest in rat (1.6 \pm 0.26$)$ as compared with $1.5 \pm 0.20$ and $0.8 \pm 0.06$ in pangolin and bat respectively (Table I). The density was however higher in pangolin (14.3 \pm 0.62 cells $/ \mathrm{mm}^{2}$ ) as against $7.7 \pm 0.24$ and $5.6 \pm 0.23$ recorded in bat and rat respectively (Table II). The zymogenic cells were characterized by their basally located nuclei and strongly basophilic granular cytoplasm which reflects their large content of rough endoplasmic reticulum.

Histological analysis. The histological investigation of the stomach in the three mammals revealed basic pattern with slight differences in the organization. The stomach of the pangolin and rat are characterized with numerous gastric pits with the zymogenic cells located towards the base of the gland, the parietal cells along the length and the mucussecreting cell at the luminal surface (Fig 1a \& b). The stomach of the bat was however different. The mucosa was observed to be organized into two distinct layers. The luminar layer (PA) being dominated by the parietal cells and few mucussecreting cells and the basal layer (ZY) consisting of zymogenic cells (Fig. 1b). The distribution of collagen fibers as evident by the high staining intensity of Van Gieson's stain (pinkish/red), revealed intense staining of collagen 


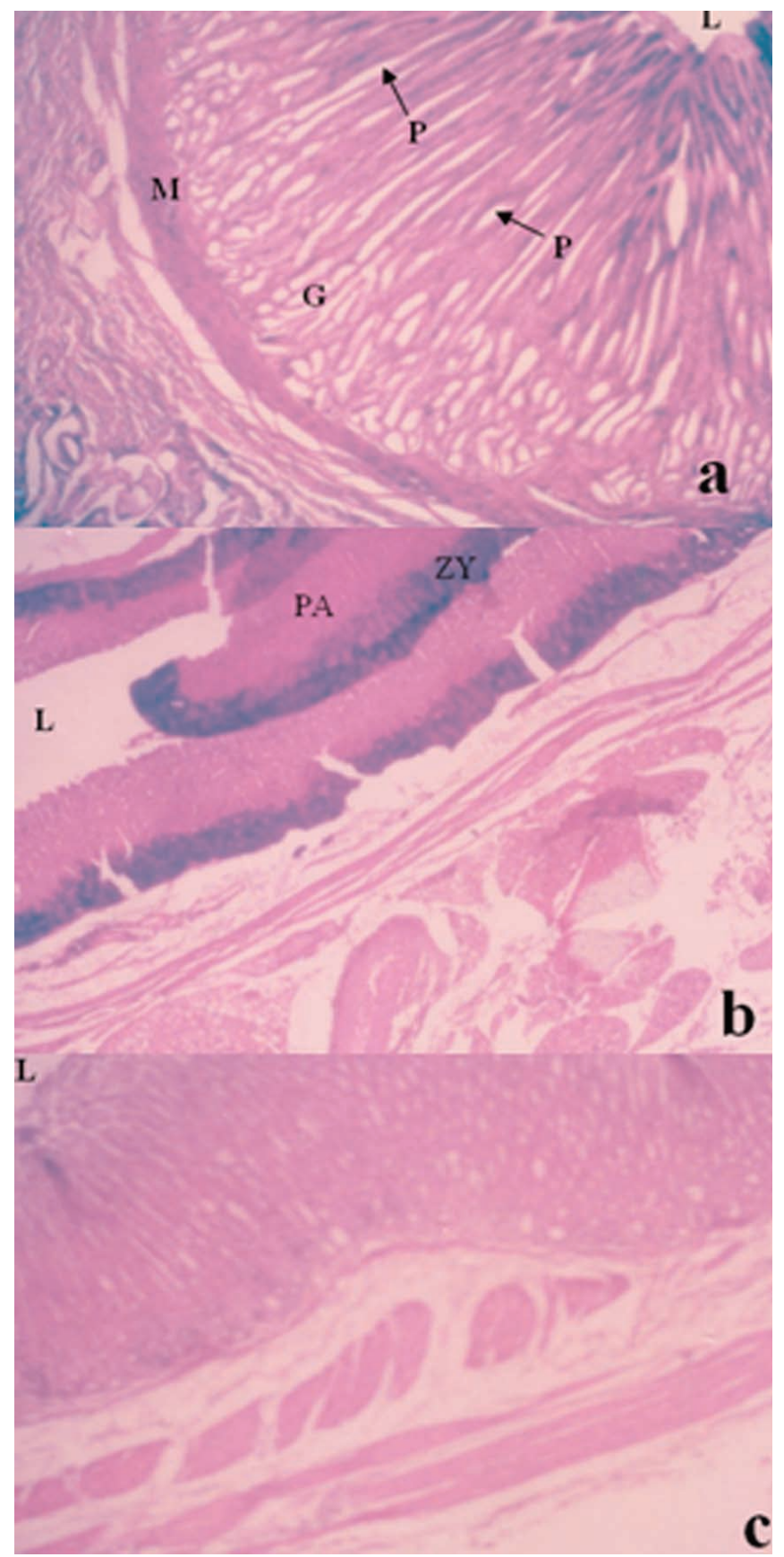

Fig. 1. Photomicrograph of the Stomach of (a) pangolin. Note the gastric pit $(\mathrm{P})$, muscularis mucosa $(\mathrm{M})$ and the numerous gastric gland $(G)$ which is absent in c. (b) bat. Note the two layers of parietal (PA) and zymogenic (ZY) cells which is absent in a and c. (c) rat. $\mathrm{H} \& \mathrm{E}(\mathrm{x} 40)$

Table I. Cellular diameter of the parietal and zymogenic cells in the stomach of pangolin, bat and rat. (Mean \pm SEM).

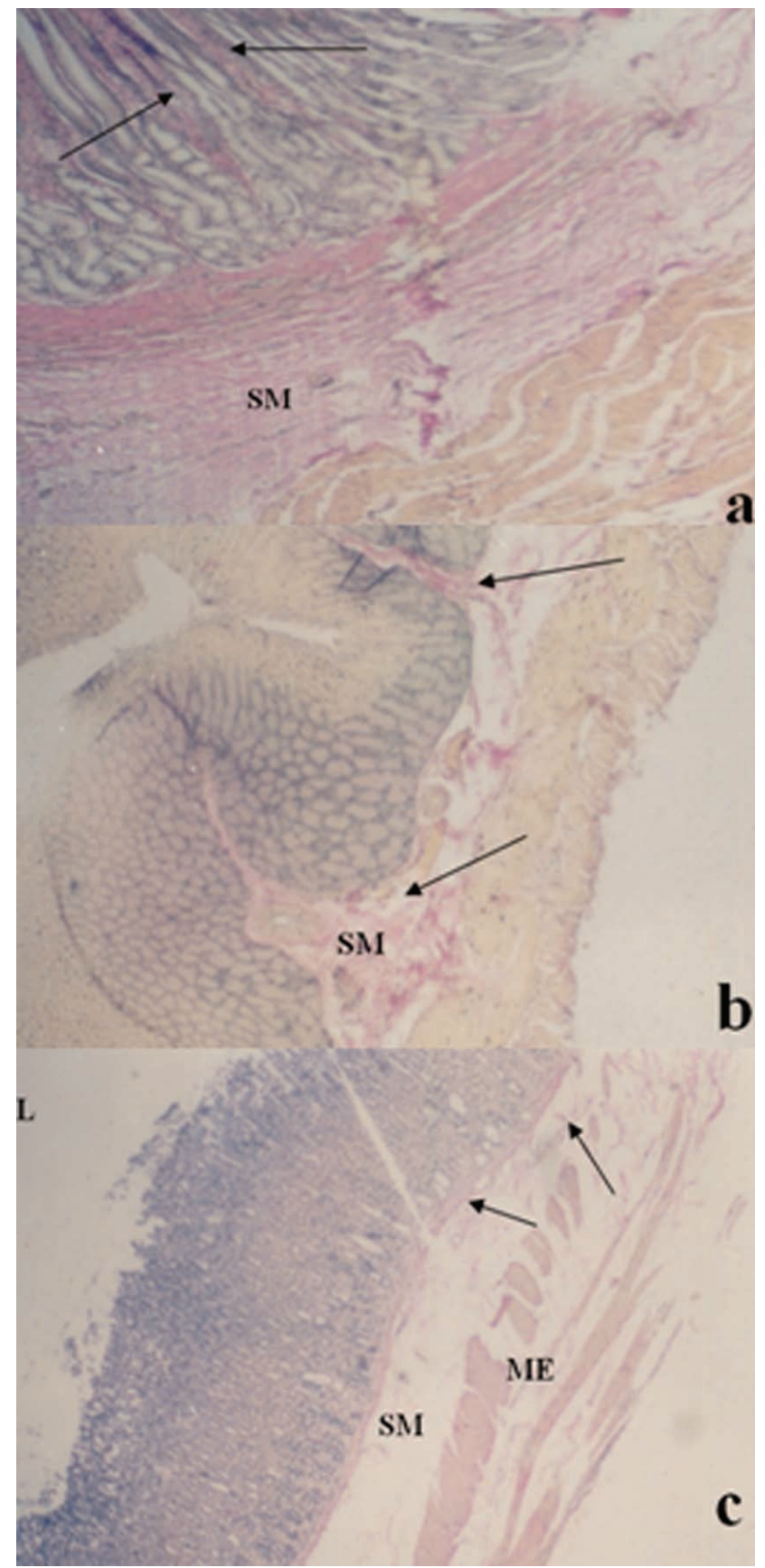

Fig. 2. Photomicrograph of the stomach of (a) pangolin. Note the high staining intensity of collagen fibers in the submucosa (SM) and along the lengths of the gastric gland (arrow). (b) bat. Arrow (indicating sparsely distributed collagen fibers in the submucosa (SM)). (c) rat. Arrow (indicating the distribution of collagen fibers in the submucosa (SM)) and amidst the muscularis externa (ME). Also note the similarity in the distribution of collagen fibers in comparison with b. Van Gieson (x 40) L= Lumen

\begin{tabular}{lccc}
\hline Cells & Pangolin & Bat & Rat \\
\hline Parietal cells & $1.6 \pm 0.11$ & $0.8 \pm 0.14^{*}$ & $6.3 \pm 0.62 * * *$ \\
Zymogenic cells & $1.5 \pm 0.20$ & $0.8 \pm 0.06^{*}$ & $1.6 \pm 0.26 * *$ \\
\hline
\end{tabular}






Fig. 3. Photomicrograph of the stomach of (a) pangolin. Note the increased distribution of elastic fibers along the lengths of the gastric gland (white arrow), in submucosa (SM) and muscularis externa (ME) as compared with $\mathrm{b}$ and $\mathrm{c}$. Also, note the blood vessel (BV). (b) bat. Note the distribution of elastic fibers in the muscularis externa (ME) almost similar to that in c. (c) rat. Note the absence of elastic fibers in the sub mucosa (SM) just as in b. Verhoeff's (x 40).

fibers in the submucosa of pangolin's stomach in contrast to the other two mammals with less staining intensity (Fig. 2a-c). The Verhoeff's stain captured the elastic fibers in the muscularis externa of the three mammals. The staining intensity of the elastic fibers (Black deposit) was again noticed to be stronger in the muscularis externa of pangolin vis-à-vis the rat and bat.

\section{DISCUSSION}

The cellular diameters of the parietal cells were $1.6 \pm 0.11,0.8 \pm 0.14$ and $6.3 \pm 0.62$ respectively in pangolin, bat and rat. It presented a significant difference $(\mathrm{p}<0.05)$ when compared in the three mammals as shown in Table I. The same observation was evident in the zymogenic cells except for the cellular diameters in pangolin $(1.5 \pm 0.20 \mu \mathrm{m})$ which was not significantly different ( $\mathrm{p}>0.05)$ when compared with that of rat (1.6 \pm $0.26 \mu \mathrm{m}$ ) (Table I). These observations revealed that the stomach in the three mammals function at different cellular level. The significant differences observed in cellular density are indication of the disparity in the concentration of gastric juices in the three mammals. This may however be related to the different diets. Previous studies revealed that the pangolin consumes insect and termites whose internal parts are rich in protein and fat (Redford \& Dorea). This explains the reason for the high zymogenic cell density observed in the stomach of pangolin. The rough endoplasmic reticulum in the cytoplasm of the zymogenic cells (Heath et al.) helps in secretion of pepsin which is an important digestive

Table II. Cellular density of the parietal and zymogenic cells in the stomach of pangolin, bat and rat. (Mean \pm SEM) $\left(\right.$ Cells $\left./ \mathrm{mm}^{2}\right)$.

\begin{tabular}{lccc}
\hline Cells & Pangolin & Bat & Rat \\
\hline Parietal cells & $8.7 \pm 0.85$ & $6.3 \pm 0.24 *$ & $5.3 \pm 0.31 * * *$ \\
Zymogenic cells & $14.30 \pm 0.62$ & $7.7 \pm 0.24 *$ & $5.6 \pm 0.23 * * *$ \\
\hline
\end{tabular}

Measured in microns; $\mathrm{n}=3$ (Mag $\mathrm{X} 400$ ). ${ }^{*} \mathrm{P}<0.05$ - significantly different vs. pangolin; $* * \mathrm{P}<0.05$ significantly different bat vs. rat. 
enzyme for protein which constitutes the bulk of pangolins diet. Pepsin hydrolyses protein into polypeptide fragments. Although the density of acid-secreting parietal cells were significantly different $(\mathrm{p}<0.05)$ in the three mammals (Table II), there role may not be too different from maintaining a low $\mathrm{pH}$ needed for the digestive enzymes to function. The high daily dietary intake of pangolin (150-200g) elucidated the reason why its parietal cellular density was higher. This is an adaptation to successfully cope with the large proportion of the ingesta. Normally, the secretions from both the zymogenic and parietal cells constitute the watery gastric juice (Heath et al.); the presence in the three mammals however, made it synonymous to what is obtainable in other mammals including man.

The slight differences observed in the structural organization of the stomach (Fig. 1), underlines their different functional implications. Thus, buttressing the conclusion of Hildebrand \& Goslow that, sections of the mammalian gut are usually specialized to suit the diet of a particular species. Ofusori et al., in their work on the stomach of pangolin, found out that the corpus is physically and chemically more active than the other parts. Despite the slight differences in the stomach of the three mammals, it was noted in Fig. 1 that there were similarities between the stomach of pangolin and rat in contrast to bat. For instance, there was a clear demarcation of the gastric glands (in the pangolin an rat) with numerous gastric pits in contrast to that of bat which had the mucosa organized into two distinct layers (Fig. 1b). Also, the zymogenic cells were observed to be well arranged at the base of the gastric gland. The similarities in the stomach of pangolin and rat may be due to their high proteinous diet (Redford \& Dorea; Caroline \& Gross).

The Van Gieson's staining method confirmed the presence of collagen fibers in the submucosa of the three mammals (Fig. 2). The staining intensity and density of the fibers were more in pangolin vis-à-vis the bat and rat. This observation is an adaptational means of coping with the high tensile strength brought about by the pronounced mechanical activities of the pangolin's stomach. This compensate for the lack of teeth in pangolin. The rat and bat for instance have teeth which break down the ingesta into fine particles before swallowing. This reduces the mechanical activities of the stomach; hence, the reason for the scanty collagen fibers observed (Fig. 2). The distribution of elastic fibers as evident by the staining intensity (black deposit) of Verhoeff's haematoxylin stain reflects an increased concentration of elastic fibers in the muscularis externa of pangolin stomach in contrast to that of bat and rat which was moderately stained (Fig. 3). This observation underlines their functional implications. The high mechanical activity which characterized the stomach of pangolin is made possible by the stretching and recoiling property of the muscularis externa. This action of the muscularis externa is brought about by these elastic fibers. The elastic fibers in the stomach of pangolin also play a vital role in the distention of the stomach when swimming (Ofusori et al.). The less mechanical activities required by the stomach of bat and rat (due to the presence of teeth) explained the reason for the moderate concentration of the elastic fibers in their muscularis externa in contrast to that of pangolin.

In conclusion, there are structural and cellular adaptations in the stomach of the three mammals (pangolin, bat and rat) in relation to their respective diet as evident in the histoarchitectutal organization.

\section{ACKNOWLEDGMENTS}

The authors are very grateful for the technical assistance of Kola Oyewole, Oluwaseun Timothy and E. Gbela of the Obafemi Awolowo University, Ile-Ife, Osun state, Nigeria.

OFUSORI D.A. \& CAXTON-MARTINS E. A. Estudio comparativo histomorfométrico del estómago de rata (Rattus norvegicus), murciélago (Eidolon helvum) y pangolín (Manis tricuspis) en relación con la dieta. .Int. J. Morphol., 26(3):669-674, 2008.

RESUMEN: En este estudio se verificaron las adaptaciones histomorfométricas comparativas en el estómago de ratas, murciélagos y pangolines en relación a la dieta. Se utilizaron para esta investigación 10 ejemplares de cada especie, de ambos sexos. Los animales fueron sacrificados después de anestesia bajo inhalación de cloroformo. Los estómago fueron extirpados, fijados en formol al $10 \%$ de solución salina y procesados para su estudio microscópico de luz. Los cortes teñidos fueron también objeto de análisis morfométrico con un aumento de X 400. Los resultados revelaron que el diámetro/densidad celular de parietal y las células cimógenas son significativamente diferentes en los tres mamíferos $(\mathrm{p}<0,05)$, con la excepción del diámetro de la células cimógenas de pangolines que no era estadísticamente significativa ( $\mathrm{p}>0,05)$ en comparación con la de rata. Por otra parte, el análisis histológico reveló ligeras diferencias en las características de organización y distribución de las fibras del tejido conjuntivo. Todas estas observaciones son un reflejo del patrón de los diferentes estómagos de los tres mamíferos, que han adoptado para hacer frente a sus respectivas dietas.

PALABRAS CLAVE: Pangolines; Murciélago; Rata; Estómago; Histomorfometría; Fibras del tejido conjuntivo. 


\section{REFERENCES}

Ayensu, E. S. Plant and bat interactions in West Africa. Ann. Mo. Bot. Grad., 61:702-27, 1974.

Caroline, M. S. \& Gross, D. M. Fiber digestion in mammals. Pak. J. Biol. Sci., 6(17):1564-73, 2003.

Griffiths, M.; Greenslade, P. J. M.; Miller, L. \& Kerle, J. A. The diet of the spring-ant eater Tachyglossus Aculeatus Acanthion in tropical habitats in the northern territory. The Beagle, 7:79-80, 1990.

Heath, J. W.; Young, B. \& Burkitt, H.G. Gastrointestinal tract. Wheater's functional histology. A Text and Color Atlas. 3rd Ed. New York, Churchill Livingstone, 1999. pp.247-70.

Hildebrand, M. \& Goslow, G. E. Analysis of vertebrate structure. $5^{\text {th }}$ ed. New York, John Wiley and sons, Inc., 2001. pp.201-17.

Kingdon, J. East African Mammals. Insectivores and Bats. London, Academic press, 1974.

Mutere, F. A. The breeding biology of equatorial vertebrates: reproduction in the fruit bat, Eidolon helvum, at $0^{\circ} 20^{\prime} \mathrm{S}$. J. Zool., 153:153-61, 1967.

Ofusori, D. A. \& Caxton-martins, E. A. A comparative histological investigation of the gastrointestinal tract in pangolin, bat and rat (preliminary study): Bk of abstract $3^{\text {rd }}$ Anatomical society of Nigeria annual conference, 2005.

Ofusori, D. A.; Caxton-Martins, E. A.; Adenowo, T. K.; Ojo, G. B.; Falana, B. A.; Komolafe, A. O.; Ayoka, A. O.; Adeeyo, A. O. \& Oluyemi, K. A. Morphometric study of the stomach of African pangolin (Manis tricuspis). Sci. Res. Essays, 2(10):465-67, 2007.

Okon, E. E. Fruit bats at Ife: Their roosting and food preferences. Nigerian field, 39:33-40, 1974.

Redford, K. H. Curious creatures to whom the ant is la haute cuisine. Smithsonian, 14:74, 1983.

Redford, K. H. Feeding and food preferences in captive and wild giant anteaters (Myremecophaga tridactyla). J. Zool., 205:559-72, 1985.

Redford, K. H. \& Dorea, J. G. The nutritional value of invertebrates with emphasis on ants and termites as food for mammals. J. Zool., 203:385-95, 1984.
Rouk, C. S. \& Glass, P. B. Comparative gastric histology of five North and Central American bats. J. Mammal., 51:45572,1970 .

Sala, M. A. M.; Matheus, M. \& Valeri, V. A. A new stereological method for estimation: the thickness of a cellular layer on random sections. Mikroskopile Wien., 38(516):127-30, 1981.

World Health Organization (WHO). Calibrating the microscope. In: Basic laboratory methods in medical parasitology, 1991.

Correspondence to:

Dr. Ofusori D. A.

Tel: +234-803-445-5715

Email davidofus234@yahoo.com

Received: 25-11-2007

Accepted: 14-07-2008 